\title{
A Lesson Plan Development Study for Higher Education Based on Needs Assessment "Graphics and Animation in Education" Course
}

\author{
Sinan Schreglmann ${ }^{1} \&$ Zekeriya Kazanc1 ${ }^{2}$ \\ ${ }^{1}$ Informatics, Kahramanmaras Sutcu Imam University, Kahramanmaras, Turkey \\ ${ }^{2}$ Faculty of Education, Cukurova University, Adana, Turkey \\ Correspondence: Sinan Schreglmann, Kahramanmaras Sutcu Imam University, Avsar Kampusu, Enformatik \\ Bölümü, Kahramanmaraş, Turkey. Tel: 90-55-5674-4221. E-mail: sinansch@gmail.com
}

Received: February 20, 2018

Accepted: March 23, 2018

Online Published: June 28, 2018

doi:10.5539/ies.v11n7p155

URL: https://doi.org/10.5539/ies.v11n7p155

\begin{abstract}
The aim of this study is to develop a lesson plan for the "Graphics and Animation in Education" course lectured in the department of Computer Education and Instructional Technology (CEIT). For this purpose, a "Needs Analysis Form for Graphics and Animation in Education Course" that includes open ended questions is produced by the program specialist and the researchers. The needs analysis form was applied to 10 instructors who have taught this course in the faculty of education. In the light of the findings derived from the needs analysis; the purpose of graphics and animation in education course was determined as: "creating e-materials which specifically comprise interactive features in order to use at various levels of education and providing students the skills to adapt these materials to be used in mobile devices". The basic strategy to use for this course is stated as "Expository" and during the course demonstration and question-and-answer methods are used. As a result, a lesson plan was developed for a unit of the graphics and animation in education course.
\end{abstract}

Keywords: higher education, lesson plan development, CEIT, graphics animation in education, needs assessment

\section{Introduction}

The need for the qualified people has been arising every day. This need which is required by the society can be responded only by the qualified education. Therefore, education constitutes the basis for all the stupendous endeavor of Turkey to become a contemporary society. It is a widely accepted fact that education takes the most important role for a country to be placed among the modern countries and then keep that place. Education is the key element for an individual to comply with the society in a balanced and healthy way. The values and life styles of the modern people have been changing rapidly today in line with the precipitous development and change in science and technology. Therefore, just like other fields, education is also obligated to change and renovate (Yagc1, 2008). This renovation can be realized only by conducting curriculum development studies regularly.

Before going through the curriculum development studies, it is necessary to comprehend the concept of the curriculum and underlying reasons of its importance. It is known that the concept of curriculum dates back to the first century BC. The oval-shaped running track in Rome where chariot race took place was called "curriculum" by Julies Caesar and his soldiers. This concrete concept as running track was transformed into an abstract concept as curriculum (Demirel, 2012a). By the increasing size of academic studies in the field of education, the researchers have come up with various definitions for curriculum. At this point, it is considered worthwhile to present some of these definitions; for instance, while Johnson (1967) defines curriculum as "structural series of intended learning outcomes". Posner (1995) states that as "series of learning outcomes which enable to decide about teaching and evaluation procedures and also plan or content design of all topics of a field with its goals and evaluation aspects" and finally Demirel (2012a) defines it as "the system of learning experiences provided for the learners through the activities planned in and out of the curriculum".

Besides, an accompanying concept which is frequently used with curriculum is the concept of curriculum development in education. While, Erden (1993) defines curriculum development in education as "designing, applying and evaluating curriculum and re-arranging them in the light of the data obtained through these evaluations".Yüksel (2000) defines it as "coordinated activities to develop curriculums through certain methods based on the current educational research" and lastly Demirel (2007) defines curriculum development as "dynamic 
relations among the goal, content, learning-teaching process and assessment elements of the curriculums."

When the process of curriculum development processes in Turkey is studied, it can be observed that the first curriculum development was conducted in 1924 for elementary schools and then gradually it was extended to middle schools (Tekısık, 1992). Recently, a new curriculum development study was conducted in 2006 in Turkey again for elementary schools and the middle school curriculums also considered to be redeveloped in the light of these studies $(4+4+4)$. The common point of previous and current curriculum development procedures is that they start at the lowest level of education and then moves to the higher levels of education. However, the most significant missing participant of these processes is that none of the higher education institutions (namely universities) were included in the curriculum development procedures (Özberk\&Özberk, 2012).

Although the current status in Turkey is not very bright, it is promising to observe that the Bologna process that started in 1998 and aims a "European Higher Education Region with more complying national higher education systems and with more transparent proficiencies" owing to the European Union, which Turkey has a close relationship and the accession negotiations have already commenced, (Adelman, 2009; Elmas, 2012; Görkem, 2014).

With the commencement of the Bologna process, which aims to minimize the differences in the educational systems among the European countries, when redeveloping the higher curriculum (in other words vocational curriculum) according to Bologna process and its positive and negative criticism such as standardization, diminishment of diversity, losing autonomy for universities, time limitations (Veiga \& Amaral, 2006; Pechar, 2007; Alexandre, Cardoso, Portela, \& Sá, 2008; Palfreyman, 2008; Birtwistle, 2009; Rauhvargers, Deane, \& Pauwels, 2009; Münch, 2010; Tahir, 2010; Morgan, 2010; Eurydice, 2012) it is not appropriate to consider the academic achievement of the students as one and only criteria. The students' accomplishments in the professional life should be considered besides their academic achievement (Finch \& Crunkilton, 1999). Therefore, a curriculum which was developed more efficiently than the previous one will help the students to obtain the knowledge, skills, attitudes and values which will be directly related to their profession after the graduation. When the vocational curriculum content of the curriculum was designed as a realistic copy of the professional world, it will enormously contribute to not only the theoretical knowledge but also their skill to transform this knowledge into application (Özberk \& Özberk, 2012). Starting exactly from this point, this research indicates its significance with its contribution to the literature by developing a curriculum for graphics and animation in education course in Computer Education and Instructional Technology (CEIT) departments in Faculties of Education. This study can be regarded as a highly important because it is the first curriculum development study specifically for the graphics and animation in education course in CEIT departments, therefore, it is hoped to guide and provide knowledge for the curriculum development for other courses within the department and for academicians teaching this course, and for those who develop e-materials for this course. In addition, with its contribution in the literature, it is expected to shed light onto the other curriculum development studies that will be conducted for other disciplines.

The basic purpose of this research is to develop a lesson plan for the graphics and animation in education course in Computer Education and Instructional Technology (CEIT) departments. In Turkey, although there are some sort of built standards in higher education level, it is a fact that there are also numerous difficulties regarding to curriculum development owing to the Bologna process recently. Therefore, this study also aims to serve as a guide for the mentioned difficulties. In order to reach this goal the study started with a needs analysis to develop "a new lesson plan" and in the light of the findings a new lesson plan was developed for one unit of the course.

\section{Method}

This study is a survey model research that aims to develop a lesson plan for "Graphics and Animation in Education" course in the department of Computer Education and Instructional Technology.

\subsection{Participants}

The participants of the study consist of 10 instructors who have lectured "Graphics and Animation in Education" course in higher education in the department of Computer Education and Instructional Technology from 10 different universities for at least one semester. In addition, it is a limitation that the students who are enrolled in the course are not included in the research.

\subsection{Data Collection}

First, "Interview form for Graphics and Animation in Education Course" was developed by the researcher and specialists for the study and used in order to reveal the needs for the development of a lesson plan for the graphics and animation in education course (Deficiency Analysis, interview technique). In this form, open-ended questions (example: what is the purpose of graphics and animation in education?) were used in a semi-structured interview 
as data gathering tool. Interview is a mutual and interactive communication process based on asking and answering questions and conducted for pre-determined serious purposes (Y1ldırım \& Simsek, 2006). In addition, interview is also a very effective and frequently preferred data-gathering tool in order to obtain information based on the people's views, experiences, complaints, and attitudes. Additionally, the semi-structured feature of the questions provides flexibility for the interviewer and also allows gathering more detailed information about the topic.

During the process of developing semi-structured questions for the Semi-strucrured review form, firstly the literature was studied and then the opinions of the academicians from curriculum development and CEIT departments were obtained. The form was created through helpful feedbacks. A pilot study was conducted in order to comprehend the language validity and purposefulness of the form. With additional feedbacks from the pilot study, the latest version of the "Interview form for Graphics and Animation in Education Course" was concluded.

\subsection{Data Analysis}

After interviewing with the academicians who have lectured graphics and animation in education course, the interview records were turn into tape scripts. In the analysis of the data, content analysis technique, which is one of the techniques for the analysis in qualitative studies, was used. The basic process of content analysis is to aggregate certain similar concepts thematically in order to organize and make them available for the readers to be comprehensible (Sadık, 2014). This process comprised coding the meaningful chunks (words, sentences, or paragraphs etc.) of the data, which were coded in a general frame. In this type of coding, the general category or the themes were pre-determined and the detailed codes are obtained after the study of the data. While the pre-determined list of codes guides the content analysis, the new codes that are appeared as a result of the study of the data were also added into the list of codes or some of them may be removed from the list of codes (Yıldirım \& Simsek, 2011). During the coding process of this research, besides studying related literature, the list of codes was constituted through the views of the academicians at Cukurova University in the faculty of education. While, the raw data texts were carefully studied, the significant parts were underlined and related codes were marked. In this process, newly obtained data were added into the list of codes and/or older codes were modified according to the new codes. Randomly selected interview texts which constitutes $25 \%$ of the whole body, were coded by a second coder separately for the reliability of the coding process. The compatibility of the codes were tested by using Miles and Huberman's (1994) formula (Reliability = agreement / agreement + disagreement x 100) and the compatibility between two coders was calculated as .94. Afterwards, the themes were constituted according to the similarities and differences and these themes were presented to the specialists of educational sciences for their opinions. Lastly, since quantification of qualitative data to some degree provide comparison of themes and categories (Y1ldirım \& Simsek, 2011). While presenting the themes and codes, a special attention was paid to be definitive and direct quotes from the interviews with academicians were used. Additionally, in order to provide validity and reliability in the study, the researcher monitored himself during the interviews to check his role in the study to reveal if he is biased or not. Therefore, a very special attention was also paid to be objective in the description and comment of the data. How the results of the study were obtained and the proofs of the inferences were reached were presented as clear and detailed as possible to make it more comprehensible for other people.

\section{Results}

\subsection{The Needs for the Curriculum for Graphics and Animation in Education Course}

The instructors participated in the study were asked that "Is there a need to develop a curriculum for the Graphics and Animation in Education course?". All of the instructors replied that with a definite yes. They have stated their reasons from various aspects. Some of the responses of the participants were as follows:

P2: "Yes, I think there is a need because an instruction cannot be without a program. Learning, especially this specific type of learning will occur with systematic learning goals. I mean there should be a method from simple to complex. When you do that without a guide, failure is inevitable."

P3: "I think there is a need because this is a very intensive course. It includes both design and visual aspects. There is both graphic editor and animation design sections. Make both of them fit in one semester within the scope of expectations is very hard.

P26: "There is a definite need. Because what to teach and how to teach is rather problematic. Each instructor tries to teach this course through different software. While some of them just teach graphic design, others focus on animations. And also, when some instructors tried to give them both, students were confused."

P9: "This course should have a curriculum. For instance, when the field exam will be administered within Public Personnel Selection Examination, the varieties in the programming languages would constitute a 
problem. Many programming languages were taught under this course. If there will be questions from the Graphics and Animation in Education course, a consensus should be reached. In this context, creating a common curriculum will be very useful and also convenient for the students that will take the exam."

\subsection{The Main Purpose of Graphics and Animation in Education Course}

When the instructors participated in the study were asked questions targeting to basic purpose of the Graphics and Animation in Education course they have provided various answers. Some participants address technical and graphic-animation aspects of the course. Some selected ideas of those were presented below:

P1: "The purpose of the course is to design graphics and animation which have effective use."

P4: "The aim of the course is to make students enable to utilize the programs existing in the market."

Some other participants stated that the purpose of the Graphics and Animation in Education course is to develop e-materials that can be used in teaching and education fields. Some selected ideas of those were presented below:

P5: "The aim of this course is enabling our students to produce effective and high quality e-materials."

P7: "The purpose of this course is to design effective graphics and animations."

P8: "The aim of this course is to equipped students with enough information to develop and teach an educational software."

P9: "I think the main purpose of this course is to utilize graphics and animation knowledge in the field of educational technology."

P10: "In the process of instructional design, our students should have a strong insight about the software they were required to use. In this context, they should be able to evaluate and use related graphics and animation software. Therefore, this is the basic purpose of the course."

\subsection{The Main Content and Material of Graphics and Animation in Education Course}

When the instructors participated in the study was asked to evaluate the Graphics and Animation in Education course from the aspect of material and content, some participants focused on technical issues. Following are the some selected ideas of them:

P6: "The software packages used during the class have both graphics and animation functions. Therefore, the basic principles of graphics should be included in the content. Namely; these are the elements of graphics, logo, symbol, etc., on the other hand, how an animation is developed and how it is designed should be taught in the animation part of the course."

P7: "It should be under three main titles: The Main Introduction, Animation, and Graphic Design. For instance; beside topics like graphic communication and graphic design, developing and animating elements of graphic design, basic animation concepts, and colors should be included in the content of the course."

P9: "Basic level of animation design software skills and platform software packages o-to be able to publish such animation products should be taught."

On the same issue, some instructors focused on the design process of educational software for their "educational quality". Following are the some selected ideas of them:

P4: "Since the content of this course includes "designing educational software", students are supposed to know the qualities of good educational software."

P10: "Story boarding for educational software, scenario development, educational interaction concepts and theoretical basis of educational software consists of the most important content of the course."

\subsection{Teaching Strategies, Methods, and Techniques to be used in Graphics and Animation in Education Course}

The instructors participated in the study were also asked about the teaching strategies/methods/techniques that they use or required to use in the Graphics and Animation in Education course. All of the participants stated that they mostly use "presentation strategy", and beside that they also use direct instruction, show and do while students were engaged with cooperative learning and individual projects, mid-term and end-term projects that produce educational software. Following are the some selected ideas of the participants:

P1: "We conduct our course based on projects. We sustain these projects through whole semester with group studies."

P7: "At the beginning of the semester, I start with direct instruction; then I practice with students through 
demonstration methods."

P8: "In order to cover chronological development of the topics, I start with direct instruction at the beginning of the term, and then I use demonstration in order to practice what I taught. Besides, we conduct projects in groups."

P10: "Direct instruction following with demonstration. I think the period of a course is not sufficient to produce an application. Therefore, I assign my students to perform weekly homework anda final project."

\section{Discussion}

Graphics and Animation in Education Course is lectured in CEIT departments of faculty of education in Turkey. The content of the course was defined by YÖK (the council of higher education) in a very restricted frame: communication through graphics, graphic design, design process and principles of design, history of graphic design, creativity in graphic design, basic design elements of graphic, application areas of graphic design, basic graphic terminology, graphical software packages and tools, animation, scripting languages in animation, animation in education (YOK, 2018). This concise definition not only causes over-flexibility for instructors who taught this course but it also induces a considerable amount of confusion among instructors and students.

While the interviewed instructors frequently claimed "an instruction without a curriculum is not possible", they also complained about the content of the course which is not clearly stated by the council of higher education. Most of the instructors stated that since the definition of the course by the Higher Education Institution is too general, they could not plan the course content appropriately and they could not stick to the schedule at the end of the semester. Therefore, the students who took this course cannot have the required knowledge and skills in order to produce e-materials. Additionally, Higher Education Institution could not state the gains of the graphics and animation in education course clearly due to the lack of a curriculum, which will serve as a guide. This situation constitutes one of the most important reasons that lead the instructors not being able to conduct effective and productive classes (Varıs, 1996).

While some instructors lie heavy on the process of designing "educational graphics" in line with their personal interest, others concentrate on producing "animation" and "computer assisted educational software" with utilizing "script" programming languages. This situation caused massive amount of differences in the quality of the teacher candidates who are graduated from CEIT departments at different universities. Another aspect of complaints by the instructors is lack of a proper order of the topics to follow during the course. Since there is not a curriculum specifically designed for the Graphics and Animation in Education Course (YOK, 2018), the instructors endeavor to provide the gains of the course for students randomly. The non-existence of a proper curriculum which is created by the specialists in higher education institutions and which can constitute a guidance for instructors not only the gains of the course but also the strategies/methods/techniques to achieve these gains are ambiguous and undetermined. Therefore, as it was supposed to be in curriculum development studies (Senemoglu, 2007), the instructors in our study expressed their common opinion as the need for development of a curriculum for graphics and animation in education course is a crucial requirement.

When the higher education institution had created and disseminated the curriculum for graphics and animation in education course, the program will be updated periodically based on the technological developments. Due to its nature, the content of the course must comply with the latest technological developments. Almost every year, dramatic progress can be observed in hardware industry. The software used in this hardware periodically upgraded as well in line with the technological progress. Therefore, the teacher candidates who took graphics and animation in education course should closely follow up cutting-edge technologies during their professional life (Hancer, Sensoy, \& Yıldırım, 2003).

The main purpose of graphics and animation in education course was stated differently by instructors from different universities. While some instructors perceive these purposes as "providing required knowledge and skills in order to create animations and simulations", "utilizing script languages at a basic level", "providing basic skills in graphic design for candidate teachers", some other instructors stated their purpose as "gaining the basic principles of graphics and animation in education", "learning required tools for this", and "succeeding to create an educational software at least at minimal level". These statements demonstrated the immense differences in main purpose of graphics and animation in education course among the universities in Turkey as it is in many other issues among them (Tayyar \& Dilseker, 2012).

After the detailed interview with the instructors, the main purposes of graphics and animation in education course for the students were determined as; "to have knowledge and skills to develop educational e-materials to meet required qualities", and "the awareness for the newly designed software in order to adapt themselves to 
cutting-edge educational technologies". In addition to this, instructors stated that; in line with the developments in software design, candidate computer teachers should have the capability to integrate these knowledge and skill to the mobile platforms. In order students to develop e-materials with multimedia features to be used in educational fields, they should not only get acquaintance with the current design software packages (such as Photoshop, Flash, Illustrator etc.) in the market but also they should have the ability to use these software packages to design educational materials. Besides, the purpose of the graphics and animation in education course is not only developing educational software but also appropriately evaluating the current educational software packages and on-line resources for their visual, technique and educational aspects. In addition to that, teacher candidates who may be planning to build an academic career should have an efficient capability to create specific educational materials which will serve as tools for their master or doctorate research. Considering all the reasons expressed here, the main purpose of graphics and animation in education course can be stated as being able to design e-materials which specifically contains interactive features (animations, simulations, and educational games etc.) to be used in various stages of education and also to integrate these materials into mobile devices as it was also similarly expressed by Agca and Bagc1 (2013).

Mobile devices, as they are ubiquitous in every field today, also play an important role in education (Bozkurt \& Ergen, 2012). Parallel to these developments, teacher candidates who are to graduate from BA programs of CEIT departments should have the required knowledge and skills to integrate the programs they have created into mobile devices like tablet PCs and mobile phones. Specifically, considering that the tablet PCs have been freely delivered to students in scope of FATIH project by the Ministry of Education in Turkey, it is very obvious that teacher candidates at some point will be required to have the capability to make educational e-materials to comply with mobile platforms. The need for this integration is estimated to be increased by the time and thus graduates of CEIT departments who are placed in every school in Turkey in instruction technologist positions will also have the mission to develop e-contents. Additionally, when three dimensional and augmented reality environments which seem to enhance their existence in many more fields are considered (Özdemir, 2013), it will be useful for students of graphics and animation in education course to get acquainted with these platforms.

Considering interactive and complex structure of educational software, it is explicit that the coding section of animation programs is very important. Therefore, it is required for students to cover the coding skills sufficiently at the end of the semester. In the very near future, thanks to game motors like Unity $3 \mathrm{D}$, which is one of the latest innovations in information technologies, it is possible to create educational software without writing even a single line of code. Thus, in order for computer teachers to comply with the era where there will be no need to learn the codes, they are required to learn design programs like Unity3D and to use them effectively when the need arises, as this will lead instructors to utilize them more effectively in their fields (Icten \& Bal, 2017).

Finally, instruction about the platforms to publish their products like animations, simulations, and educational software should be provided for the students of graphics and animation in education course. Naturally, there will be platform differences between animations designed to be published on-line and animations designed to be presented in an application. Therefore, in order to make educational software designs to work effectively and properly, the students should have the knowledge about the complying platforms and the skills to publish their e-materials on those platforms (Isik et al., 2010).

Unfortunately, a course book or any e-material specifically designed for graphics and animation in education course does not exist. Inevitably, the instructors lecturing this course have been facing certain difficulties. The lack of any official materials for this course causes serious handicaps for reaching to the main gains of the course (Hutchinson, 2007). Although the instructors have created their own authentic "course notes" with their restricted feasibilities, this effort is far from a certain "quality standard". Therefore, resource materials specific for graphics and animation in education course should immediately designed and published by related authorities and institutions.

When the instructors use demonstration method in the sections of graphics and animation in education course where application skills are required, they will require students to involve in the class actively and also they will contribute to their level of retention. Additionally, when these instructors utilize useful combination of audio-visual materials for demonstration, it will help students to increase their motivation and facilitate the class environment efficiently. However, the instructors should have comprehensive preparations before class in order not to face troubles during demonstration method. It should be remembered that being enable to conduct an efficient demonstration method requires having ample amount of knowledge and skills in educational technologies (Demirel, 2012b).

Primarily, the main content of graphics and animation in education course should be graphic design since it might 
not be possible for students to create animations before they are sufficiently trained in graphic design. In that sense, they cannot compose the graphics to be animated and put them in a meaningful order. Therefore, firstly the students should know the basic principles of graphic design, basic elements of graphic design (such as symbols, logo, pictogram etc.) and also basic knowledge of colors which fortifies the meaning of the graphics. Additionally, since these principles and elements are utilized in digital environments now, students are required to have the knowledge and skills to use basic graphic design software packages (such as Photoshop, CorelDraw, illustrator etc.). In order to reinforce these knowledge and skills, students can create e-materials like; logo, flyer, educational posters etc. Before moving into the animation phase, students should comprehend the principles of multimedia design thoroughly (Mayer, 2001). Therefore, the prerequisite for graphics and animation in education course is to assimilate the principles of multimedia design.

Once the students grasp basic insights of graphic design, then they can move to basic principles of animation and animation design. Afterwards, students are expected to learn theoretical frameworks of animation production, basic animation techniques, creating scenario and storyboards. When the students have grasped the theoretical infra-structure, then they can start animation through primary examples like joint movement, turning wheel, bouncing ball etc. The students can practice their learned subjects in computer laboratory on animation programs (Flash, Edge Animate etc.). After accomplishing basic level of animations by animating static images, the students are now ready to integrate animations with programming codes (such as ActionScript) in order to produce educational simulations, animation and e-materials with interactive features. In addition to these topics, students can be introduced to a new system called Unity3D. Students can also be guided about publishing their works on-line which requires knowledge on platforms (like HTML5).

Unfortunately, there is not any course book specifically designed to be used in graphics and animation in education course. Therefore, the instructors who lecture this course use their own documents as course material. Naturally the materials produced by different instructors have different contents. In addition to these materials, students benefit from various educational videos and documents created by various people on the internet. For instance, Ministry of Education has produced some e-resources for their own trainee (MEGEP, 2017) and sometimes instructors also suggest these documents to their students.

In order to make graphics and animation in education course to be more productive, not only instructors but also students who take this course should have a certain readiness level. The readiness level of students should be followed by the instructor closely and thus missing topics of the students can be compensated by the instructor. On the other hand, the demonstration method mentioned above may not be efficient in over-crowded classes that suffer from lack of required technologies (Demirel, 2012b). Before starting the graphics and animation in education course, the instructor should prepare required environment and devices, present the explanations about the graphics/animation/program to be designed, provide feedbacks, and repeat the designed graphics/animation/program with other students and thus all students are able to see potential errors. For the evaluation of the course; missing or under achieved topics of the course can be detected and commented through question-and answer method, students can be given individual or group projects to be controlled, and finally the outcome of these projects can be evaluated with/by the students (Kolb, 1984).

During the graphics and animation in education class, there are certain points that the instructors should pay attention. For instance, while designing an educational animation in the class, the instructor should follow the design steps of the animation and should ask short-answer questions to the students in order to check how much did they comprehend these steps. Afterwards, these stages of the animation should be evaluated and commented by the students in the class by emphasizing the significant points. Additionally, in order to use the time period in class efficiently, the instructor should determine the demonstration time of the e-material. Finally, the product created after the demonstration should be evaluated again with the students and missing points should be detected and corrected. Furthermore, the e-material intended to be designed in class should be checked by the instructor to assure that it is suitable for the skills and experiences of the students. Lastly, the demonstration should be conducted clearly by using simple tools (Demiriz, 2001), and also the e-material created during this phase should be disseminated to the students at the end of the course.

Naturally, graphics and animation in education course is supposed to be conducted in computer laboratory. The students should immediately practice what they have learned in an environment which has required physical and technique infra-structure. Therefore, the strategy to be used during the course is firstly "expository teaching". While the instructor is presenting the course, after providing basic concepts of graphic design, he or she should provide elements and generalizations for students according to the consecutiveness principles. In this process, while the instructor is active, located in the center, and prefer lecture method, students are semi-active (Ausubel, 1968). The students are supposed to provide the examples after the instructor had explained the basic concept and 
principles of educational animation. During this process, the instructor should have intensive interactions with students using question-and-answer method. Afterwards, the most important phase of graphics and animation in education course will start; demonstration and practice where the instructor endeavors to provide animation design skills. Since audial and visual elements are integrated in the animation design program, a very efficient teaching-learning environment can be provided. The instructor should show the best applications of the process through demonstration methods and should ask students to practice the same thing in their computers at the computer laboratory. These methods should be preferred in order to explain the subjects, to transfer the knowledge into skills by practice, and to provide gains at application level during graphics and animation in education course. While lecture methods can be used to found theoretical basis through questions like "What is graphic design?", "What are the elements of graphic design?" etc., demonstration method can be used for providing psycho-motor skills of graphic animation.

As its nature dictates, graphics and animation in education course is based on individual works of students on computer to design certain e-materials. Students themselves must integrate graphics and animation skills with their personal experiences. However, after the interviews with instructors, their common opinion was emerged as to assign students to produce an e-material at the end of the semester as their final project. In other words, students were supposed to create an educational material like courseware, educational game, interactive animation etc. in order to demonstrate and perform what they have learned during whole semester. Since these projects require long-term preparation and production processes, they are very demanding for students to create these e-materials themselves. Therefore, in one hand, encouraging team works for these final projects were strongly suggested by instructors but on the other hand, instructors also advise to restrict the project groups by two to four students in order to balance the contribution of individuals within the group. Generally, students cannot organize role distribution equally within the group or even when they distribute tasks and responsibilities in balance, they face troubles in sticking to their schedule and deadlines. Therefore, instructors should avoid building over-crowded project groups for the final projects of graphics and animation in education course. In fact, the distribution of roles and responsibilities of the students within the group can be conducted by the instructor when the need arises. At the final phase of the study, a draft of curriculum for graphics and animation in education course was designed based on the data derived from the needs analysis. The draft of curriculum was designed only for the topic of "A Simple animation design (Bouncing ball)" (see Appendix).

Due to the limitations in time, place and resources, this study was conducted by the views of 10 instructors. It can be suggested to repeat the same study with a larger group of instructors and at an extended period of time in detail. Besides, this study was also limited to curriculum development of only one unit of the graphics and animation in education course. Although this constitutes certain limitation for the study, it can be easily and effectively extended to all other units of graphics and animation in education course in the curriculum of CEIT departments.

\section{References}

Adelman, C. (2009). The Bologna Processor U.S. Eyes: Re-learning Higher Education in the Age of Convergence. Washington, DC: Institute for Higher Education Policy.

Agca, K. R., \& Bagc1, H. (2013). Egitimde Mobil Araclarin Kullanimina Iliskin Ögrenci Görüsleri. Journal of Research in Education and Teaching, 2(4), 295-302.

Alexandre, F., Cardoso, A. R., Portela, M., \& Sá, C. (2008). Implementing the Bologna Process. Retrieved from http://www.voxeu.org/article/implementing-bologna-processshorter-firstdegree.html

Ausubel, D. P. (1968). Educational psychology. A cognitive view. New York: Holt, Rinehart and Winston, Inc.

Birtw1stle, T. (2009). Towards 2010 (and then beyond)-the context of the Bologna Process. Assessment in Education: Principles, Policy \& Practice, 16(1), 55-63. https://doi.org/10.1080/09695940802704088

Demirel, Ö. (2007). Kuramdan Uygulamaya Egitimde Program Gelistirme. Ankara: PegemAPub.

Demirel, Ö. (2012a). Egitimde program gelistirme. Ankara: PegemAPub.

Demirel, Ö. (2012b). Ögretim ilke ve yöntemleri ögretme sanatı. Ankara: Pegem yayınc1lık.

Demiriz, S. (2001). Okulöncesi egitim kurumlarındaki fen ve doga etkinlikleri ile ilgili uygulamaların belirlenmesi. IV. Fen Bilimleri Egitimi Kongresi 2000, Bildiriler, Ankara: M.E. s 86.

Elmas, M. (2012). Bologna process: Apply or not apply. Journal of Higher Education and Science, 44, $137-141$. https://doi.org/10.5961/jhes.2012.044

Erden, M. (1993). Egitimde program degerlendirme. Birinci Bask1. Ankara: PegemAPub. 
Eurobarometer. (2007). Perceptions of higher education reforms: Survey among teaching professionals in higher education institutions, in the 27 member states and Croatia, Iceland, Norway and Turkey. The Gallup organization. Retrieved from http://ec.europa.eu/public_opinion/flash/fl198_en.pdf

Eurydice. (2012). The European Higher Education Area in 2012: Bologna Process Implementation Report. Retrieved from http://eacea.ec.europa.eu/education/Eurydice/documents/thematic_reports/138EN.pdf

Finch, C. R., \& Crunkilton, J. R. (1999). Curriculum Development in Vocational and Technical Education: Planning, Content, and Implementation (5th ed.). Boston: Allyn \& Bacon Inc.

Görkem, H. (2014). Bologna Sürecinde Maliye Bölümleri ve Maliye Egitimi: Ögrenci Görüsleri. Journal of Life Economics, 1, 13-40. https://doi.org/10.15637/jlecon.201416988

Grove, J. (2012). Bologna not to taste of Germancritics. Times Higher Education. Retrieved http://www.timeshighereducation.co.uk/story.asp?storycode $=419845$

Hancer, A. H., Sensoy, Ö., \& Yıldırım, H. İ. (2003). İlkögretimde Cagdas Fen Bilgisi Ögretiminin Önemi Ve Nasıl Olması Gerektigi Üzerine Bir Degerlendirme. Pamukkale Üniversitesi Egitim Fakültesi Dergisi, 13(1), 80 .

Hutchinson, A. (2007). Literature Review Exploring the Integration of Interactive Whiteboards in K-12 Education. Retrieved from http://www.innovativelearning.ca/seclearntech/documents/smart-iwb-litreview 07.pdf

İcten, T., \& Bal, G. (2017). Review of Recent Developments and Applications in Augmented Reality. GU J Sci, Part C, 5(2), 111-136.

Isık, A. H., Karacı, A., Özkaraca, O., \& Birogul, S. (2010). Web Tabanlı Es Zamanlı (Senkron) Uzaktan Egitim Sistemlerinin Karsılastırmall Analizi. Akademik Bilisim'10 - XII. Akademik Bilisim Konferansı Bildirileri 10 - 12 Subat 2010 Mugla, Turkey.

Johnson, M. (1967). Definitions and Models in Curriculum Theory. Educational Theory, 17(2), 130-146. https://doi.org/10.1111/j.1741-5446.1967.tb00295.x

Koch, J. (2009). In Europe, skeptics of new 3-year degrees abound academics and students question the value of shorter higher-education cycles and the motivations driving this Continental shift. The Chronicle of Higher Education. Retrieved from http://chronicle.com/article/In-Europe-Skeptics-of- New-/44467.html

Kolb, D. A. (1984). Experiential Learning: Experience as the Source of Learning and Development. New Jersey: Prentice Hall, Inc., Engle wood Cliffs.

MEGEP. (2017). Gelismis Animasyonlar. Retrieved from http://www.megep.meb.gov.tr/mte_program_modul/ moduller_pdf/Gelismis\%20Animasyonlar.pdf

Morgan, J. (2010). Audit over load. Times Higher Education. Retrieved from $\mathrm{http} / / / \mathrm{www}$.timeshighereducation.co.uk/story.asp?storycode $=410612$

Münch, R. (2010). Bologna, orthecapitalization of education. Retrieved from http://www.eurozine.com/articles/2010-07-01 munch-en.html

Özberk, E. H., \& Özberk, E. (2012). Yüksekögretimde Ihtiyac Analizi Teknigine Dayalı Program Gelistirme Calısması: Ölcme Ve Degerlendirme Dersi Modeli. Egitim ve Ögretim Arastırmaları Dergisi, 4(1), 216-225.

Özdemir, M. (2013). Experimental Studies on Learning with Augmented Reality Technology: A Systematic Review. Mersin University Journal of the Faculty of Education, 13(2), 609-632.

Palfreyman, D. (2008). The legal impact of Bologna implementation: exploring criticisms and critiques of the Bologna process. Education and the Law, 20(3), 249-257. https://doi.org/10.1080/09539960903003974

Pechar, H. (2007). "The Bologna process" a European response to global competition in higher education. The Canadian Journal of Higher Education, 37(3), 109-125.

Posner, G. J. (1995). Analyzing the Curriculum. New York: McGraw-Hill Inc.

Rauhvargers, A., Deane, C., \& Pauwels, W. (2009). Bologna Process Stock taking Report. Retrieved from http://www.ond.vlaanderen.be/hogerdijs/bologna/conference/documents/Stocktakg_rep_2009_Final.pdf

Sadik, F. (2014). Child And Environmental Issues: The Investigation of Children' Perceptions and Views on Environmental Issues. The Journal of Acadeofc Social Science, 2(8), 114-133.

Senemoglu, N. (2007). Gelisim, Ögrenme ve Ögretim (Kuramdan Uygulamaya). Ankara: Gönül yayıncılık. 
Tahir, T. (2010). The irresistible rise of academic bureaucracy. The Guardian. Retrieved from http://www.guardian.co.uk/education//academic-bureaucracy-risemanagers- higher-education.html

Tayyar, N., \& Dilseker, F. (2012). Devlet Ve Vakif Üniversitelerinde Hizmet Kalitesi Ve Imajin Ögrenci Memnuniyetine Etkisi. Mugla Üniversitesi Sosyal Bilimler Enstitüsü Dergisi, 12(28), 184-203.

Tekısık, H. (1992). Ögretmenler Toplumda Layık Oldukları Statüye Nasıl Kavusur? Cagdas Egitim Dergisi, 175 , 254-266.

Varıs, F. (1996). Egitimde Program Gelistirme. Ankara: Alkım Yayınları.

Veiga, A., \& Amaral, A. (2006). The open method of coordination and the implementation of the Bologna process. Tertiary Education Management, 12, 283-295. https://doi.org/10.1080/13583883.2006.9967174

Yagcı R. (2008). Sosyal bilgiler ögretiminde elestirel düsünme: ilkögretim 5. sinff sosyal bilgiler ögretiminde ögretmenlerin elestirel düsünme becerilerini gelistirmek icin uyguladıkları etkinliklerin degerlendirilmesi. Yüksek Lisans Tezi. Cukurova Üniversitesi Sosyal Bilimler Enstitüsü, Adana, Turkey.

Yıldırım, A., \& Simsek, H. (2011). Sosyal Bilimlerde Nitel Arastırma Yöntemleri (8.Baskı), Seckin Pub., Ankara.

YOK. (2018). Bilgisayar ve Ögretim Teknolojileri Ögretmenligi Lisans Programi. Retrieved from http://www.yok.gov.tr/documents/10279/49665/bilgisayarogretim/86c92e-3973-41c6-9e98-ed6d816391db

Yüksel, S. (2000). Milli egitim bakanlıgındaki program gelistirme calısmalarının degerlendirilmesi. Kuram ve Uygulamada Egitim Yönetimi, 24, 581-609.

\section{Appendix}

Lesson Plan Sample

\begin{tabular}{|l|l|}
\hline \multicolumn{2}{|c|}{ PART I } \\
\hline Lesson Name & Graphics and Animation in Education \\
\hline Content/Topic & Animation Design \\
\hline Subject & A Simple animation design (Bouncing ball) \\
\hline Time & 90 min. $(45+45 \mathrm{~min})$. \\
\hline \multicolumn{2}{|c|}{ PARTII } \\
\hline $\begin{array}{l}\text { Objectives/Learning Outcomes: } \\
\text { At the end of the class students should be able to; } \\
\text { Know and use the interface of the animation design program and create a simple animation.. }\end{array}$ \\
\hline
\end{tabular}

\begin{tabular}{|l|l|}
\hline Learning Method/Technique: & $\begin{array}{l}\text { Expository Teaching Method, Demonstration } \\
\text { Technique, Practice }\end{array}$ \\
\hline Materials/Equipment: & Computer, Projection \\
\hline
\end{tabular}

\section{ACTIONS}

Gain Attention: The instructor shows an animation of a bouncing ball and asks students "How do you think we can design that?" "Do you think you can this same animation today? Then let sufficient amount of students to answer this question in order to attract their attention.

Inform Learners of Objectives: The instructor tells students that: "After learning the interface of Adobe Flash design and animation program and basic principles of animation, you will be able to create very useful educational animations".

Stimulate Recall of Prior Learning: The instructor reminds students the basic notions of graphics and animation in order to detect and complete their preliminary information about the topic.

Present Stimulus: The instructor runs the Adobe Flash program and introduces the interface by reflecting it 
through the projector. One by one, the instructor introduces the buttons on the tools box and tells their functions and operating logic. Then she/he draws a little ball on the scene and transforms this into a MovieClip and then using timeline panel, she/he designs a bouncing animation.

Provide Learner Guidance: The students try to imitate the actions that the instructor done in the computer and reflected through screen. During this phase, the instructor wanders among the students and guides them when it is necessary.

Elicit Performance: The instructor asks students to perform what they have learned: "What is the purpose of Flash program?, What is the function of timeline?, How can you design a simple bouncing ball animation?" The students are required to answer these questions by doing them on their computer.

Provide Feedback: The instructor evaluates the answers she/he got during elicit performance phase and positively reinforce correct answers. The instructor also detects the wrong answers and provides indirect feedbacks to compensate missing topics.

Assess Performance: At the at end of the class, the instructor requests students to create a .fla file, save this file and then publish it in various file formats, and also create an animated design in their computer.

Enhance Retention and Transfer: The students were asked to create an airplane propeller animation.

\section{PART III}

\begin{tabular}{|c|c|c|}
\hline $\begin{array}{l}\text { Assessment } \\
\text { and } \\
\text { Evaluation }\end{array}$ & \multicolumn{2}{|c|}{$\begin{array}{l}\text { 1. Assessment and evaluation for individual learning activities } \\
\text { - How to create and save a design file with .fla extension? } \\
\text { - How to export and publish a .flafile and how to create a .swf file? } \\
\text { - Ho to create a new scene and add new frames? How to work on timeline? } \\
\text { - Hhat is the operating logic of timeline panel? } \\
\text { - How to create an animation of bouncing ball? }\end{array}$} \\
\hline \multicolumn{3}{|r|}{ PART IV } \\
\hline \multicolumn{2}{|c|}{ Conclusion of the application of the plan } & $\begin{array}{l}\text { The topic was lectured within two class hours an } \\
\text { aim of the course was reached after the evaluatic } \\
\text { the class. }\end{array}$ \\
\hline
\end{tabular}

\section{Copyrights}

Copyright for this article is retained by the author(s), with first publication rights granted to the journal.

This is an open-access article distributed under the terms and conditions of the Creative Commons Attribution license (http://creativecommons.org/licenses/by/4.0/). 